Newfoundland and Labrador Studies

\title{
Mark Callanan and James Langer, eds. The Breakwater Book of Contemporary Newfoundland Poetry.
}

\section{Paul Chafe}

Volume 29, Number 1, Spring 2014

URI: https://id.erudit.org/iderudit/1062250ar

DOI: https://doi.org/10.7202/1062250ar

See table of contents

Publisher(s)

Faculty of Arts, Memorial University

\section{ISSN}

1719-1726 (print)

$1715-1430$ (digital)

Explore this journal

Cite this review

Chafe, P. (2014). Review of [Mark Callanan and James Langer, eds. The Breakwater Book of Contemporary Newfoundland Poetry.] Newfoundland and Labrador Studies, 29(1). https://doi.org/10.7202/1062250ar viewed online.

https://apropos.erudit.org/en/users/policy-on-use/ 


\section{Reviews}

about how Newfoundlanders perceived their Canadian visitors and Confederation, although this last point is hinted at more than explicitly discussed. Anxieties about nationhood and foreign interactions that sought to place Newfoundland in a subservient and dependent role are also drawn to the surface and the authors present a balanced argument regarding the Newfoundland government's ability to meet residents' wartime needs and contribute to an international war. The oral testimonies of more than 50 Newfoundlanders who lived through the period add a personal touch to the narrative and refresh the authors' central argument that the war did not produce a clear separation between the home and war fronts. The book is visually stunning - with more than 100 photographs - and well researched, and will appeal to both the general public and undergraduates.

Bonnie White

St. Francis Xavier University

Mark Callanan and James Langer, eds. The Breakwater Book of Contemporary Newfoundland Poetry. St. John's: Breakwater Books, 2013.

ISBN 978-1-55081-408-8

The editors of The Breakwater Book of Contemporary Newfoundland Poetry owe me a night's sleep. I began reading the collection late one night and upon completing it early in the morning, went to my bookshelf and returned with Tom Dawe's In Hardy Country, Michael Crummey's Hard Light, John Steffler's The Grey Islands, and Agnes Walsh's Going Around with Bachelors. As the sun was rising, I had pilfered my daughter's collection and was reading Al Pittman's Down by Jim Long's Stage. Soon after, sleep-deprived but poetry-enriched, I was online purchasing works by Ken Babstock, Richard Greene, and Sue Sinclair. If an anthology such as this is meant to whet the reader's appetite, then editors Mark Callanan and James Langer do a fine job setting the table. The Breakwater Book of Contemporary Newfoundland Poetry is a perfect introductory collection for casual or uninitiated readers, a comprehensive enough text for students and teachers, and a slender, portable book for those who prefer not to travel without the best that Newfoundland poetry has to offer. And unlike 
the rather bloated and unnecessary The Backyards of Heaven: An Anthology of Contemporary Poetry from Ireland and Newfoundland and Labrador, Callanan and Langer's collection narrows its focus to established and energizing poets and gives each of them ample page time to enrapture the reader.

The back cover informs readers this collection gathers "the strongest poets to emerge from Newfoundland since the death of E.J. Pratt in 1964." Provided with such a tidy half-century window, one is tempted to decipher a Zeitgeist arching its way through the works of all eleven poets. Not surprisingly, considering that the notion of a singular preoccupation shared by artists from the same place is often the contrivance of critics, there are as many contradictions as there are commonalities here. Both the new and seasoned reader of Newfoundland poetry will find some interesting parallels that could easily be confirmed or challenged by further reading within the collection. Readers will find poems focusing on the history of Newfoundland, like Crummey's "Newfoundland Sealing Disaster" or Greene's "The White Fleet," a beautiful multi-faceted ode to the fishermen of Portugal's White Fleet, who for years summered in St. John's: "Public order bore with their offences, / and the constabulary made nothing / of loud drunkenness and small affrays, / because their charities stood in balance: / at any late hour, a Portuguese crew / would genially pour out their twenty pints / to save some stranger bleeding at St. Clare's" (117). In many of these poems, the twentieth-century condition appears to manifest itself in Newfoundland through the act of leaving home, whether that departure is the individual's choice as represented in Green's "Crossing the Straits," or the government-sponsored relocation of outport communities captured in Dawe's "Abandoned Outport" and Pittman's "Gran Glover's Dream," a response to the David Blackwood painting of the same name in which the evacuating occupants of a community are witnessed through the window of a home they are leaving behind: "These are the islanders / leaving their island / huddled into the wind / they are going away / out to where there is nothing / they have gone away to nothing" (18).

As someone who was taken to his fair share of Irish Catholic wakes as a child, I was not shocked to discover that death is a repeated theme in a collection of Newfoundland poets. Pittman's "Final Farewell," Mary Dalton's "The Cross-handed Bed," Carmelita McGrath's "My Father's Ghost," Crummey’s "The Late MacBeth" and Sinclair's "Forever" all focus on that final shuffling off. Walsh's "The Laying Out, 1956" is a recitation on how to prepare a body while "I Solemn" captures how attending a wake and being lifted by an adult to see (and kiss!) the corpse is a rite of passage for many Newfoundland youth: "On the 


\section{Reviews}

floor again I was given a triangle of ham sandwich / and a saucer of hot, sweet tea. 'She's a grand good girl now / after going to a poor soul's wake.' And all the women smiled / sorrowfully at me. And I solemn. / Solemn as could be" (146).

Readers will sense in these poems what it is to move, live, and love in a Newfoundland space. Steffler's brilliant "That Night We Were Ravenous" follows the course of an evening that begins with the near-death experience of a highway collision with a moose: "I swerved / through a grove of legs startled by pavement ... it was the / landscape doing a moose, a cow / moose, / most improbable forest device. She danced / over the roof of our car in moccasins" (59). This manifestation of "our deaths come briefly forward to say hello" is countered later with life-affirming actions: "That night we were ravenous. We talked, gulping, waving our / forks. We entered one another like animals entering woods" $(60,61)$. Pittman's "Another Night in Crawley's Cove," Dawe's "Outport Christmas," McGrath's "Before Electricity, Demons Were a Regular Occurrence," and Babstock's "Methodist Hatchet" all tackle particular peculiarities of Newfoundland society and culture. The particular peculiarities of the many Newfoundland voices are rendered wonderfully by Mary Dalton. She has received much credit for scouring The Dictionary of Newfoundland English for her source material, but not enough credit for her ear for the spoken word, which she converts to the page so well in "Down the Bay": "It's so barren down there / A crow's got to bring / A stick to pitch on" (74).

Perhaps the most wonderful discovery awaiting readers of this text is the fact that Newfoundland poetry is not always about Newfoundland. Babstock's "The Minds of Higher Animals," Dawe's "If Sonnets Were in Fashion," and McGrath's "Love and the Swan" are just some of the best non-Newfoundlandcentric "Newfoundland" poems here. Pretty much all of the work by Sinclair and Patrick Warner is placeless, presenting observations and conditions that are more universal or personal than place-specific. This, of course, raises the troubling question of what is a Newfoundland poet or poem, and how does this collection define and justify itself. In the week following the publication of The Breakwater Book of Contemporary Newfoundland Poetry, I was contacted by three people, each asking the same question: “Isn’t Ken Babstock from Ontario?" Of the eleven poets in this collection, only six are Newfoundland-born poets who still make their home in Newfoundland (this includes Pittman, who died in 2001). The editors claim in their prefatory note that in making their decision on whose work was to be included in their anthology they "have considered any poet who developed - either by birth or residence - a strong relationship with the island of Newfoundland prior to the publication of their 
first full-length collection of poetry" (8). This is as good a reason as any, I suppose, but every list is contentious and I am sure some readers will wonder why poets like Randall Maggs, Susan Ingersoll, or Des Walsh are not represented here. For me, the greatest omission is Don McKay, who did not develop a strong relationship with Newfoundland prior to the publication of his first collection, but is nonetheless the unofficial poet laureate of Newfoundland fossils and minerals (see Paradoxides). Who sings for Labradorite or the Ediacara biota, Mr. Callanan and Mr. Langer? Don McKay, that's who.

So is a Newfoundland poem about Newfoundland or by a Newfoundlander? How is "A History of the Lombards" by Irish-born- and -raised Warner a Newfoundland poem? Is it because Warner was living in Newfoundland when he wrote it? Melville was landlocked in Pittsfield, Massachusetts, when he wrote Moby Dick. Does that make his nautical opus a "Berkshire" novel? Perhaps these questions about Newfoundland poetry could have been answered or at least considered had the collection been thickened by some critical matter. To their credit, Callanan and Langer do not explain away the lack of criticism and analysis with the clichéd excuse that they want to "let the poems speak for themselves." I hear in that caveat the same truth I disguise when I tell people I choose to let my garden grow wild: to do otherwise is a lot of work and I do not care to do it. Perhaps students and scholars of Newfoundland poetry can take as a challenge this fine collection of well-crafted poems and produce a text that analyzes the under-analyzed work of Sinclair, Babstock, Greene, and others. Perhaps Newfoundland and Labrador Studies should publish an issue dedicated to the critical examination of contemporary Newfoundland poetry. Perhaps that issue could be guest-edited by a certain displaced Newfoundlander teaching in Ontario.

Paul Chafe

Ryerson University 